\title{
Development and Testing of a Spiral Type Water Wheel Pumping System
}

\author{
Fanesh Kumar $^{1 *}$, Jitendra Sinha ${ }^{2}$ and Kamalkant ${ }^{3}$ \\ Department of Soil and Water Engineering, SVCAET \& RS, Raipur-492012, \\ Chhattisgarh, India \\ *Corresponding author
}

\section{A B S T R A C T}

\begin{tabular}{l} 
Ke y w o r d s \\
Kinetic energy, \\
Discharge, Carrying \\
water, Delivery \\
head, Inlet, Outlet, \\
Spiral Type Water \\
Wheel Pumping \\
System (STWWPS) \\
\hline Article Info \\
\hline $\begin{array}{l}\text { Accepted: } \\
\text { 26 April } 2020 \\
\text { Available Online: } \\
\text { 10 May 2020 }\end{array}$ \\
\hline
\end{tabular}

\section{Keywords}

Kinetic energy, water, Delivery head, Inlet, Outlet, Spiral Type Water Wheel Pumping System (STWWPS

\begin{abstract}
Pumping system powered by kinetic energy of water from nearby nallah can be a cheap, efficient and precise way of delivering water to nearby farm pond/open well. The pumping system is simple to develop, install, operate and very much cater to the need of rural remote area. It may be suitable for un-electrified as well as unreliable electric supply area provided suitable site conditions are available. The major components of spiral tube water wheel pumping system include rim, inlet valve, housing, flexible pipe, bearing, T-joint etc. The spiral type water wheel pumping system (STWWPS) was developed and tested. Water enters from the inlet into the spiral tube, which is under rotation because of the kinetic energy of flowing water. The water reaches to the centre of housing then the succeeding water pushes the preceding to go ahead and the water comes out from the housing, which is delivered towards the outlet. Under the operating condition of 0.30 to $0.46 \mathrm{~m}$ of water depth with flow velocity of $0.41 \mathrm{~ms}^{-1}$ to $0.54 \mathrm{~ms}^{-1}$ and carrying distance of $1 \mathrm{~m}$ to $20 \mathrm{~m}$, the discharge of 180 to 270lphwas obtained.
\end{abstract}

\section{Introduction}

India is an agricultural country and there are many rivulets, stream, rivers and elevated canals. Under drop/fall condition the water flows with great velocity. The kinetic energy of flowing water can be utilized for some useful work like pumping. The energy of flowing water can be utilized for lifting and carrying water for irrigation purposes, filing the small ponds and also for other rural works in remote areas. It can also be used at canal/nallah to operate a pumping system. A canal is frequently used for convenience and distribution of water for irrigation and to store water to farm pond/well.

Nowadays, experiments are carried out by adopting the several methods for carrying water in remote areas. The spiral water wheel pump system could also be useful for carrying the water without disturbing the side bund of 
canal. The spiral tube pumping system, as per its name it includes water wheel and tubes. A wheel on which the spiral tube mounted and it rotates due to force of water flow which is acting on the blade of wheel. Water enters from the inlet side and because of rotation of wheel, the water moves spirally inside the tube. The water passes in tube flowing towards the centre of wheel. The center wheel consist a hollow axel which is work as a discharge outlet (Patel et al., 2017). The construction of a spiral tube water wheel system is very simple and it consists of hollow axel supported by housing bearing which are mounted on stand.

Kassab et al., (2005) did experiments with the design and testing of multi- layers coil pump to obtain the pump performance under different design parameters including method of winding the hose around the drum in multilayers, inlet and outlet position, hose inner diameter, drum diameter. For this purpose, a coil pump was designed, constructed and tested. The experimental results showed that the three layers coil pump has better performance than single and two layer pumps. In addition, improved pump performance is obtained when the pump inlet placed at the top end in the case of multi-layer pumps. Moreover, increase the coil hose inner diameter and/or drum outer diameter results in better coil pump performance.

Flow velocity does play an influential role in the performance of water wheel as it is directly linked with the kinetic energy but measuring the 3D topographic characteristics and velocity field of a flowing water surface is difficult. Chandler, et al., (2014) demonstrated that a high degree of measurement and marking automation is possible in a flume environment, where lighting influences can be highly controlled. When applied to a real river it is apparent that only lower degrees of automation are practicable. They also demonstrated that although some automation is possible for point measurement, point matching needs to be manually guided in a natural environment where lighting cannot be controlled. Mishra et al., (2016) reported that due to escalating prices of electricity and fuels, it is becoming more difficult to pump water by piston and reciprocating pump. They conducted study to simplify the problem and pump water at small scale with the easiest of economical and green technique. They pumped water by using water wheel being run from the power of flowing water, by wrapping a tube around the plane of wheel to form a coil shape. The inlet of tube is $1 / 3$ submerged in water, when flowing water strikes the wheel then the wheel rotates and water goes down on the tube with air which is compressed in spiral tube.

The water contained in the spiral compresses air between them as they travel around the tube and both air and water are expelled under pressure into the hollow axel of the wheel. Kumar Vinay (2017) performed a review on design and performance evaluation of overshot; breasts hot and undershot low cost waterwheel. He concluded that most of the hydro projects have continuous 24 hour's availability and high efficiency around $81 \%$ in the present time.

Currently the focus of Chhattisgarh government is on 4 aspects, namely: Narwa (Water Resources Management), Garuva (Cattle Management), Ghurva (Composting Management) and Badi (Nutritional Management). This study "Development and Testing of Spiral Type Water Wheel Pumping System" has been taken and a spiral type water wheel pumping system (STWWPS) has been developed. The system can link the Narwa (Water Resources Management) programme with Badi (Nutritional Management) programme in remote/unelectrified area. 


\section{Materials and Methods}

The present research work has been carried out in the field of Krishi Vigyan Kendra, Raipur, I.G.K.V., Raipur (C.G.), which is situated in the central part of Chhattisgarh at latitude $21^{\circ} 23^{\prime} 32^{\prime \prime} \mathrm{N}$ and longitude $81^{\circ} 71^{\prime} 35^{\prime \prime}$ E. Testing was also done at Mandher Branch Canal Tulasi (C.G.), Mandher Branch Canal Kendri (C.G.) and other suitable locations of canal command area in Chhattisgarh state. A spiral type water wheel pumping system was developed in the form of carrying water while utilizing kinetic energy of water. 3D drawing of STWWPS was done with the help of AutoCAD software. The overall dimension of Spiral tube operated pump is $109.8 \mathrm{~cm}$ in height, $67 \mathrm{~cm}$ in length and width is $63 \mathrm{~cm}$. This is shown in Fig. 1.

The system comprises of the following components

\section{Frame}

The frame forms the main body of the STWWPS on which various components are assembled and it gives stability to the unit during the pumping operation. The frame consists of the front portion on which the wheel is mounted at the center. The overall dimension of frame is $65 \mathrm{~cm}$ in total height, $67 \mathrm{~cm}$ in length and width is $63 \mathrm{~cm}$.

\section{Rim}

A part of a wheel to which the tire is attached in a common bicycle and is an important part of the mechanism. The diameter of the rim is $63.5 \mathrm{~cm}$ and flexible hose pipe is fixed spirally over the spoke of the wheel.

\section{Housing}

The hollow pipes acting as axle are supported by housing bearing and mounted on stand.
The dimension of housing is $2.5 \mathrm{~cm}$ diameter and length is $74 \mathrm{~cm}$.

\section{Flexible pipe}

The flexible hosepipe is fixed in a spiral manner in the rim and makes the spiral wheel. A coil is formed from flexible pipe and is actually conveying water from the bottom line of the wheel to the centre of the wheel.

\section{Block bearing}

Block bearing is used to transfer axial and radial loads from the structure supporting it. The dimension of bearing is $2.5 \mathrm{~cm}$ inner diameter

\section{Union valve}

Rotary union valve is used to connect one side with rotating discharge pipe and other side with stationary discharge pipe.

\section{Development and setup of spiral tube water wheel pumping system}

Essential components as mentioned above were systematically assembled in the workshop of Swami Vivekanand College of Agricultural Engineering and Technology \& Research Station, IGKV, Raipur. The source of power for rotating the wheel is kinetic energy of flowing water. Therefore, rectangular blades are welded to periphery of rim for creating the push effect.

The flexible hose pipe is fastened with the spoke of the wheel using clamps and G.I. wire around the rim in a spiral manner to create the spiral water wheel. A wide mouth HDPE bottle (open from bottom for collecting water) is used in such a way that open bottom end faces the flowing water while the other end (without lid) is fixed with the flexible hose pipe. 
Other end of the hose pipe is fixed with central housing pipe with the help of a TEE and nipple. Both of these hollow pipes are supported by hosing block bearing which are mounted on stand, so that wheel will rotate continuously over stand by the force of the flowing water. One end of the central housing pipe is closed while the other end acts as the rotating discharge pipe. This end is now connected with a rotary union valve. Other end of the rotary union valve is connected with stationary discharge pipe for delivering water to nearby farm pond/open well.

Working of spiral tube water wheel pumping system

Flexible Hose pipe is fixed spirally in a wheel having rectangular plates in its periphery. The flowing water pushes the plates hence the wheel rotates. One end of tube is fixed with a wide mouth HDPE bottle (open from bottom for collecting water) inlet while the other end is attached in housing at the center of the pumping system. Water enters from the inlet side and because of rotation of wheel, the water moves spirally inside the tube. The water reaches the center of housing while the succeeding water pushes the preceding to go ahead; this way the water comes out from the housing, which is delivered toward the outlet.

\section{Test procedure of developed water wheel} pumping system

\section{Measurement of flow velocity}

Float method has been used for determining the flow velocity.

$\mathrm{V}($ Velocity $)=\frac{\text { Distance traveled by the float }}{\text { time taken for travel }}$

\section{Measurement of water depth}

Depth of water is vertical distance between top levels of water to the bottom layer of canal surface. The depth was calculated by average sum of all the depth divided by the total number of observations.

\section{Measurement of RPM}

As the wheel rotates slowly, hence, revolutions per minute (RPM) of the water wheel was measured by marking the wheel with contrast colour at selected place matched up with the centre of stationary stand and time was recorded in stop watch of a mobile phone.

\section{Determination of discharge by the pumping system}

Volumetric method was used to measure discharge by the pumping system. A graduated bucket of 20 litre capacity was filled and the respective time was measured with a stopwatch. The pump discharge was calculated by dividing the amount of water by the measured time in liter per minutes (lpm).

\section{Performance testing of spiral type water wheel pumping system}

STWWPS was tested at different water head and flow velocity for the associated discharge at certain carrying distance. The results of the experimentation have been presented in the form of tables and graphs. Each point on a graph represents an average of three observations, falling within \pm 10 per cent variation. The STWWPS is tested at different locations under different head conditions viz. fisheries dam, Mandhar branch canal Tulsi and other nearby minor canal as shown in Fig 2.Naegel, et al., (1991) conducted nearly 1600 individual tests on the performance of water wheel pumping system and established that the pump was most efficient (over 50per cent) with a high head, a slow rotational speed, a smaller-diameter tube, and with a scoop of 100 to120 per cent of the outer coil. 


\section{Results and Discussion}

Lifting and carrying water for irrigation to nearby pond/open well requires energy and it's a challenge to do that without electricity, diesel or solar power. In this study an attempt has been made if this can be met out utilizing the kinetic energy of flowing water. A spiral tube water wheel pumping system was developed and tested at different water depth and water velocity for lifting and carrying water and its associated discharge. STWWPS was fixed in the canal and flow of water in the canal was regulated through a regulator provided at the outlet. With increase in discharge the increase in depth of flow and flow velocity in canal was observed.

\section{Performance evaluation of STWWPS for carrying water}

STWWPSis most suitable to higher velocity of water in upstream side and lower water depth in downstream side. Higher water depth in downstream side actually retards the movement of wheel. Testing is done at different flow velocity as per suction head, delivery head and carrying distance with associated discharge.

When the water depth in the canal varies from $0.30 \mathrm{~m}$ to $0.46 \mathrm{~m}$ with velocity of water varying from 0.41 to $0.54 \mathrm{~ms}^{-1}$, it was seen that the discharge varying from 0.114 to 0.193 lps. So, it was found that velocity affecting the discharge very much as presented in table 1 and described in figure 3 . When the water depth in the canal varies from $0.30 \mathrm{~m}$ to 0.46 $\mathrm{m}$ with velocity of water varying from 0.41 to $0.54 \mathrm{~ms}^{-1}$, it was seen that the discharge varying from 0.070 to $0.098 \mathrm{lps}$ at carrying distance of $10 \mathrm{~m}$. Positive effect of flow velocity on discharge by STWWPS is as presented in table 2 and described in figure 4.Similarly, the discharge by STWWPS under same water depth and flow velocity but for carrying distance of $20 \mathrm{~m}$, it was found to be varying from 0.050 to $0.076 \mathrm{lps}$ as presented in table 3 and described in figure 5.

More discharge of STWWPS with more flow velocity in canal is because of availability of higher kinetic energy for rotating the wheel. Repeated and frequent push by the coming water from inlet into the STWWPS might be resulting in better pumping action.

Considering the high efficiency of the pumping system at high heads and slows peeds of rotation, its non-use of fossil fuel and its adaptability to existing natural conditions (i.e. where a strong streamflow, streamin narrow rivers or irrigation canalsis available), spiral pumps are an excellent alternative, in particular for developing countries (Naegel et al., 1991).

Table.1 Testing of STWWPS under varying flow velocity with $1 \mathrm{~m}$ distance of carrying

\begin{tabular}{|c|c|c|c|c|c|c|}
\hline $\begin{array}{l}\text { S. } \\
\text { No. }\end{array}$ & $\begin{array}{c}\text { Water } \\
\text { Depth (m) }\end{array}$ & $\begin{array}{c}\text { Water } \\
\text { Velocity } \\
\left(\mathbf{m s}^{-1}\right)\end{array}$ & $\begin{array}{c}\text { Wheel } \\
\text { RPM }\end{array}$ & $\begin{array}{c}\text { Distance } \\
(\mathbf{m})\end{array}$ & $\begin{array}{c}\text { Discharge } \\
\text { (lps) }\end{array}$ & $\begin{array}{c}\text { Discharge } \\
\text { (lpd) }\end{array}$ \\
\hline $\mathbf{1 .}$ & 0.30 & 0.41 & 23 & 1 & 0.114 & 9849 \\
\hline $\mathbf{2 .}$ & 0.34 & 0.45 & 25 & 1 & 0.129 & 11145 \\
\hline $\mathbf{3 .}$ & 0.38 & 0.48 & 26 & 1 & 0.147 & 12700 \\
\hline $\mathbf{4 .}$ & 0.42 & 0.52 & 28 & 1 & 0.172 & 14860 \\
\hline $\mathbf{5 .}$ & 0.46 & 0.54 & 29 & 1 & 0.193 & 16675 \\
\hline
\end{tabular}


Table.2 Testing of STWWPS under varying flow velocity with $10 \mathrm{~m}$ distance of carrying

\begin{tabular}{|c|c|c|c|c|c|c|}
\hline $\begin{array}{c}\text { S. } \\
\text { No. }\end{array}$ & $\begin{array}{c}\text { Water } \\
\text { Depth } \\
(\mathbf{m})\end{array}$ & $\begin{array}{c}\text { Water } \\
\text { Velocity } \\
\left(\mathbf{m s}^{-\mathbf{1}} \mathbf{)}\right.\end{array}$ & $\begin{array}{c}\text { Wheel } \\
\text { RPM }\end{array}$ & $\begin{array}{c}\text { Distance } \\
\mathbf{( m )}\end{array}$ & $\begin{array}{c}\text { Discharge } \\
(\mathbf{l p s})\end{array}$ & $\begin{array}{c}\text { Discharge } \\
\text { (lpd) }\end{array}$ \\
\hline $\mathbf{1 .}$ & 0.30 & 0.41 & 23 & 10 & 0.070 & 6022 \\
\hline $\mathbf{2 .}$ & 0.34 & 0.45 & 25 & 10 & 0.074 & 6419 \\
\hline $\mathbf{3 .}$ & 0.38 & 0.48 & 26 & 10 & 0.081 & 6972 \\
\hline $\mathbf{4 .}$ & 0.42 & 0.52 & 28 & 10 & 0.088 & 7594 \\
\hline $\mathbf{5 .}$ & 0.46 & 0.54 & 29 & 10 & 0.098 & 8467 \\
\hline
\end{tabular}

Table.3 Testing of STWWPS under varying flow velocity with $20 \mathrm{~m}$ distance of carrying

\begin{tabular}{|c|c|c|c|c|c|c|}
\hline S. No. & $\begin{array}{c}\text { Water } \\
\text { Depth } \\
(\mathbf{m})\end{array}$ & $\begin{array}{c}\text { Water } \\
\text { Velocity } \\
\left(\mathbf{m s}^{-\mathbf{1}} \mathbf{)}\right.\end{array}$ & $\begin{array}{c}\text { Wheel } \\
\text { RPM }\end{array}$ & $\begin{array}{c}\text { Distance } \\
\mathbf{( m )}\end{array}$ & $\begin{array}{c}\text { Discharge } \\
\text { (lps) }\end{array}$ & $\begin{array}{c}\text { Discharge } \\
\text { (lpd) }\end{array}$ \\
\hline $\mathbf{1 .}$ & 0.30 & 0.41 & 23 & 20 & 0.050 & 4354. \\
\hline $\mathbf{2 .}$ & 0.34 & 0.45 & 25 & 20 & 0.055 & 4717 \\
\hline $\mathbf{3 .}$ & 0.38 & 0.48 & 26 & 20 & 0.058 & 5028 \\
\hline $\mathbf{4 .}$ & 0.42 & 0.52 & 28 & 20 & 0.065 & 5650 \\
\hline $\mathbf{5 .}$ & 0.46 & 0.54 & 28 & 20 & 0.076 & 6566 \\
\hline
\end{tabular}

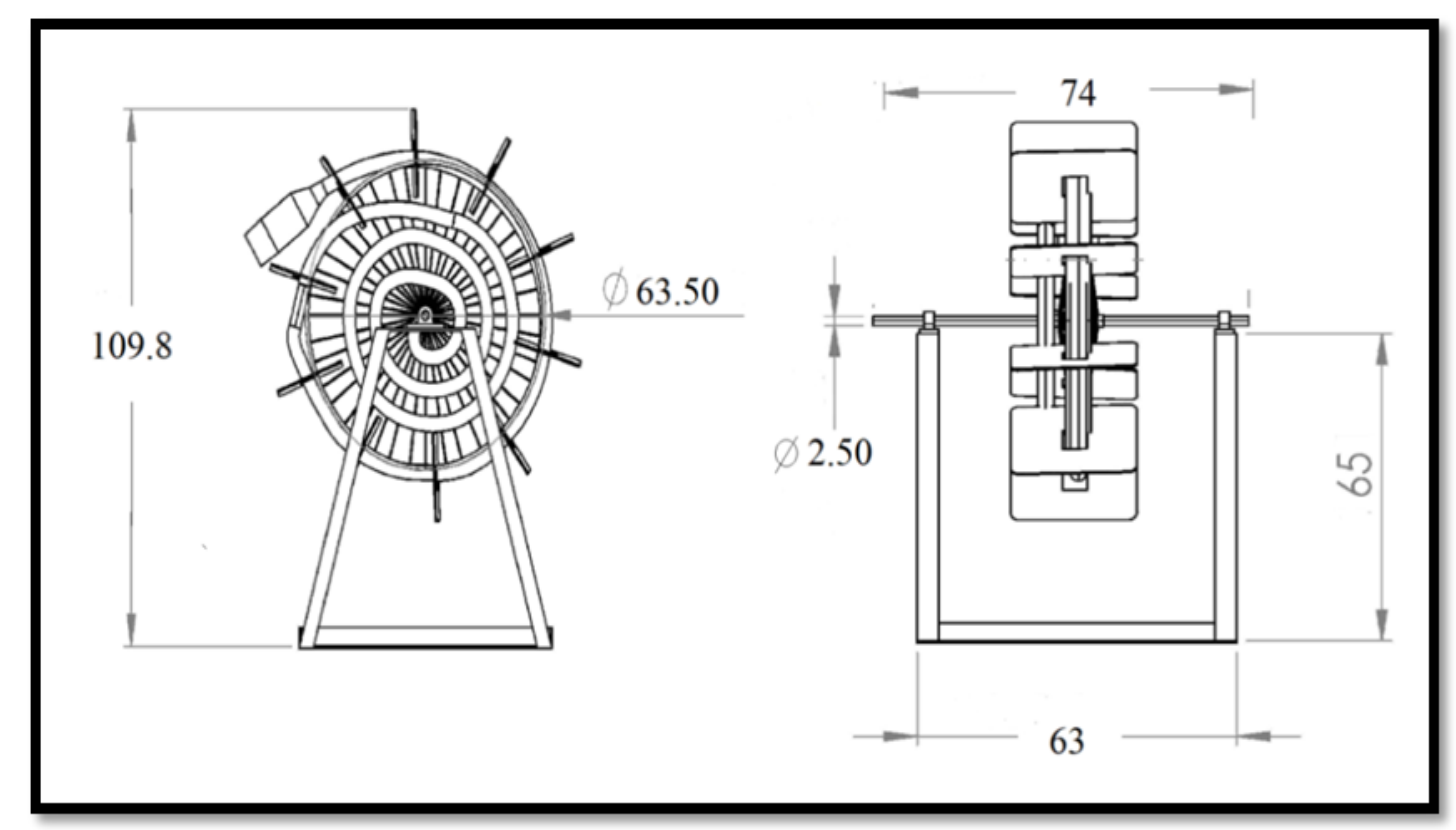

Fig.1 Spiral type water wheel pumping system 


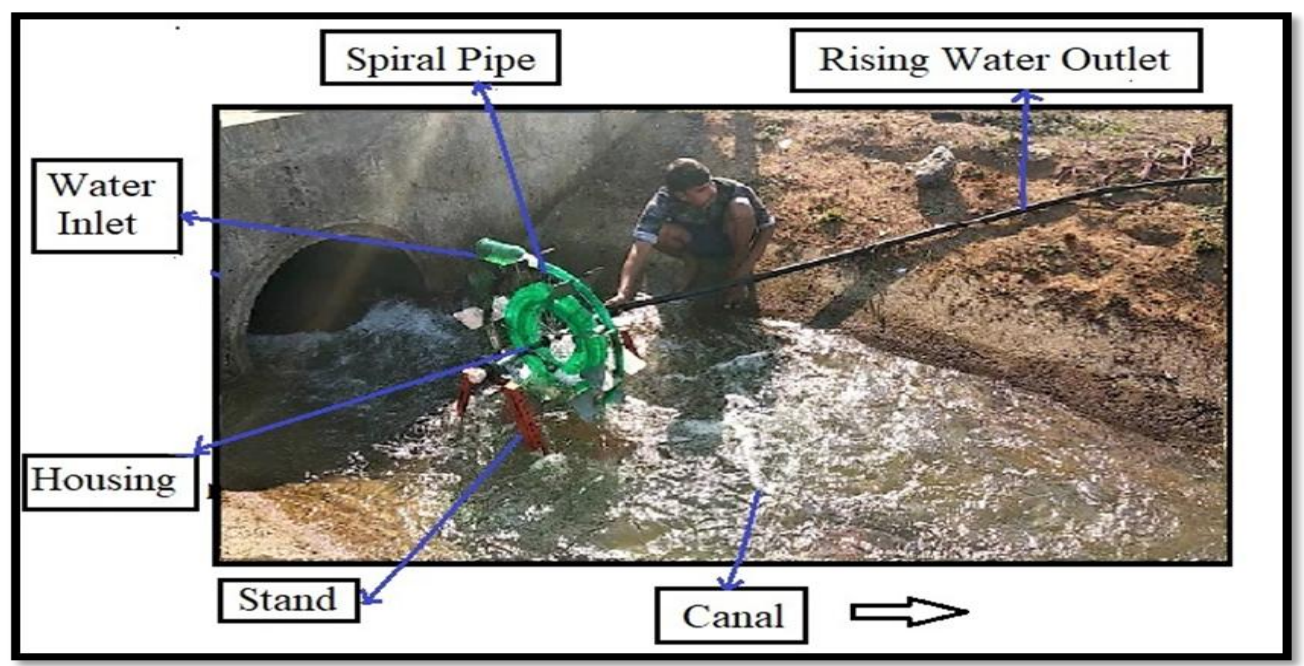

Fig.2 Testing of spiral tube water wheel pumping system at village Kendri

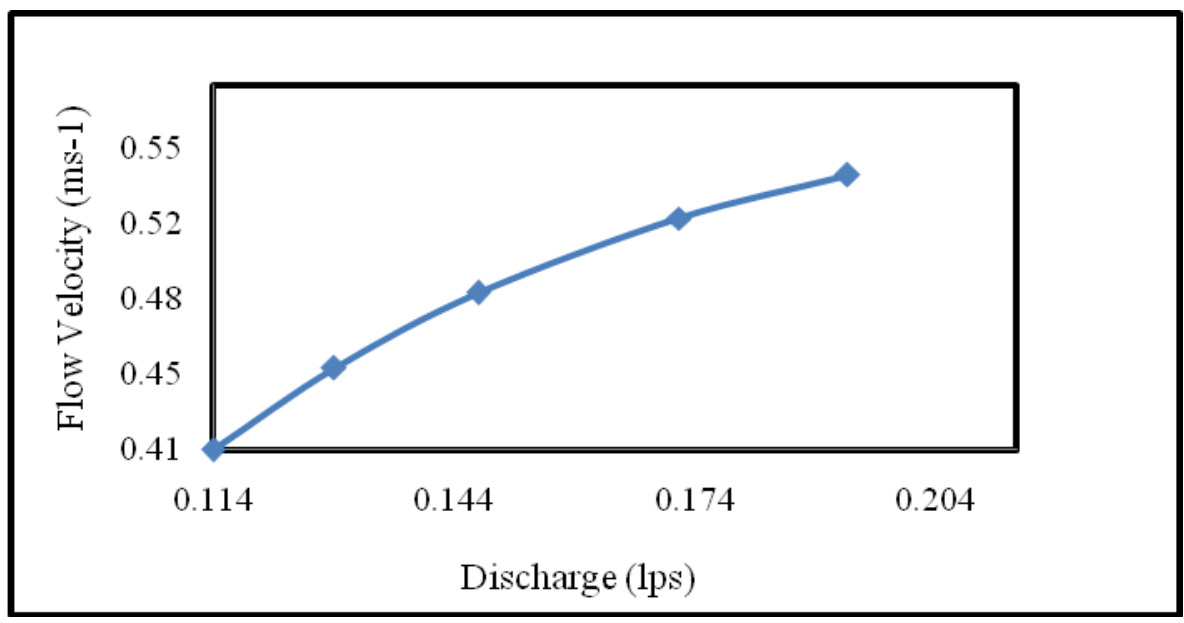

Fig.3 Relationship between discharges through STWWPS with $1 \mathrm{~m}$ distance of carrying under varying flow velocity in canal

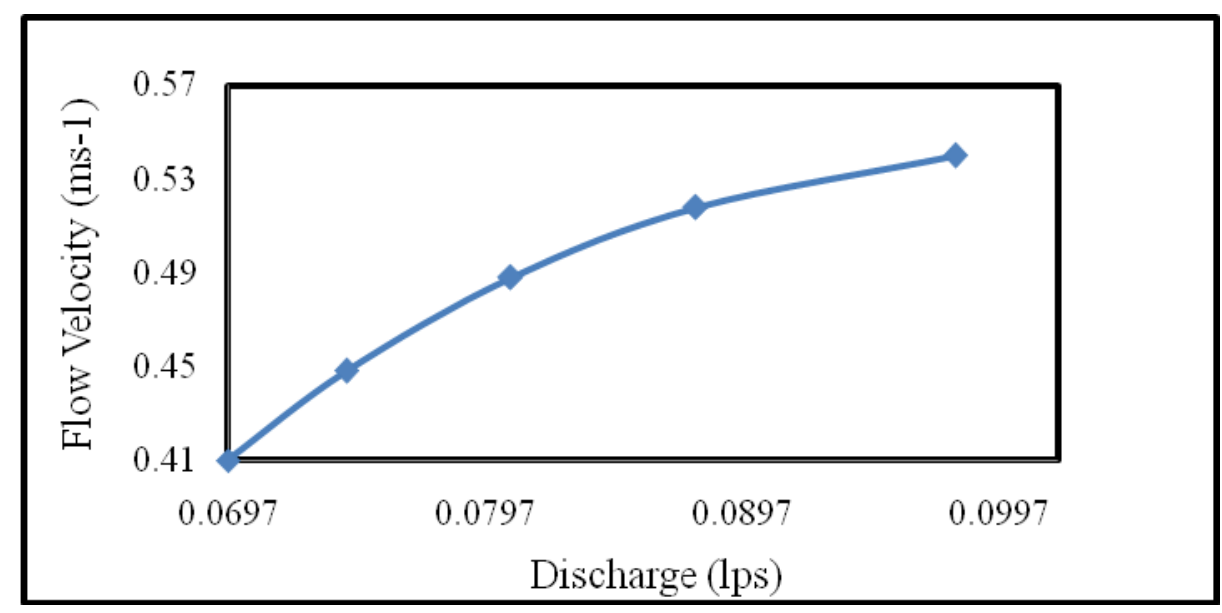

Fig.4 Relationship between discharges through STWWPS with $10 \mathrm{~m}$ distance of carrying under varying flow velocity in canal 


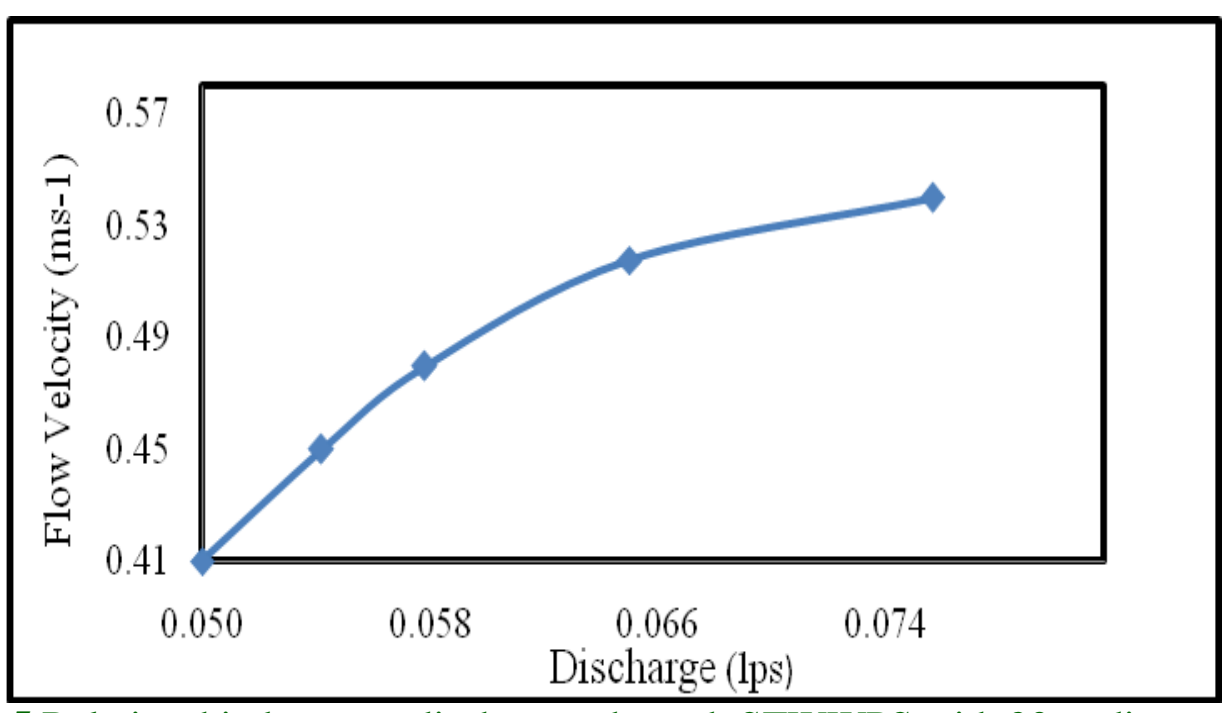

Fig.5 Relationship between discharges through STWWPS with $20 \mathrm{~m}$ distance of carrying under varying flow velocity in canal

The spiral type water wheel pumping system (STWWPS) was developed with M. S. plate frame of $0.67 \mathrm{~m}$ to $0.63 \mathrm{~m}$, spiral water wheel $0.63 \mathrm{~m}$ diameter, housing pipe $0.74 \mathrm{~m}$ length, and with overall height of $1.09 \mathrm{~m}$. The system can give a discharge of $6566 \mathrm{lpd}$ to $16675 \mathrm{lpd}$ at water velocity of $0.54 \mathrm{~ms}^{-1}$ and carrying distance of $20 \mathrm{~m}$ to $1 \mathrm{~m}$ far from the pumping site and can constantly feed open well or pond utilizing the kinetic energy of flowing water only.

\section{Acknowledgement}

The authors are thankful to the Department of Soil and Water Engineering, SVCAET and RS, I.G.K.V., Raipur (C.G.) for providing the facilities required for conducting this study.

\section{References}

Chandler. H., Ferrira, E., Wackrow, R., Shiono, K.2014. Surface and velocity measurement river and flume, The International Archives of the Photogrammetry, Remote Sensing and Spatial Information Sciences, $5: 23$ -
25.

Kassab, S.Z., Ahmed, A., Abdel, N., Sayed, E., Abdel, B. 2005. Coil Pump Performance under Variable Operating Conditions. Ninth International Water Technology Conference, Pp. 665-672.

Kumar Vinay, 2017. A Review on Design and Performance Evaluation of Low Cost Water Wheel. International Journal of Engineering Technology Science and Research, 4 (6); pp - 393 397.www.ijetsr.com.

Mishra, P., Verma, D., Sankhe, H., More, R. 2016. Spiral tube water wheel pump. International Journal on Recent and Innovation Trends in Computing and Communication, 4 (4): pp - 137 - 139.

Naegel, L.C.A., Real, J. G., Mazaredo, A.M. 1991.Desining a spiral pump for irrigation. Water lines volume - 10 NO.2: $p \mathrm{p}-30-31$.

Patel, P. K., Patel, M., Prajapati, K., Rajput, N., Patel, U. 2017.Design of spiral tube agricultural water wheel pump. International Journal of Applied Research in Science and Engineering, 2 (1): pp- 560-565. 


\section{How to cite this article:}

Fanesh Kumar, Jitendra Sinha and Kamalkant. 2020. Development and Testing of a Spiral Type Water Wheel Pumping System. Int.J.Curr.Microbiol.App.Sci. 9(05): 3061-3069. doi: https://doi.org/10.20546/ijcmas.2020.905.364 